\title{
Measuring Interfaith Spirituality: Cross-Cultural Validation of Interfaith Spirituality Scale and Its Short Version
}

\author{
Ibrahim Kira1,2* (, Neslihan Arıcı Özcan ${ }^{3}$, Justyna Kucharska4, Hanaa Shuwiekh', \\ Amer Kanaan', Mireille Bujold-Bugeaud ${ }^{1}$ \\ ${ }^{1}$ Center for Cumulative Trauma Studies, Stone Mountain, GA, USA \\ ${ }^{2}$ Center for Stress, Trauma and Resiliency, Georgia State University, Atlanta, GA, USA \\ ${ }^{3}$ T. C. İstanbul Medeniyet University, Amthal, H. Al-Huwailah, College of Social Sciences, Kuwait University, Kuwait, Kuwait \\ ${ }^{4}$ University of Westminster, London, UK \\ ${ }^{5}$ Fayoum University, Fayoum, Egypt \\ ${ }^{6}$ Vimplegant3, 21114, Malmo, Sweden \\ Email: ^kiraaref@aol.com
}

How to cite this paper: Kira, I., Özcan, N. A., Kucharska, J., Shuwiekh, H., Kanaan, A., \& Bujold-Bugeaud, M. (2021). Measuring Interfaith Spirituality: Cross-Cultural Validation of Interfaith Spirituality Scale and Its Short Version. Psychology, 12, 1960-1981. https://doi.org/10.4236/psych.2021.1212119

Received: November 10, 2021

Accepted: December 7, 2021

Published: December 10, 2021

Copyright (C) 2021 by author(s) and Scientific Research Publishing Inc. This work is licensed under the Creative Commons Attribution International License (CC BY 4.0).

http://creativecommons.org/licenses/by/4.0/ Open Access

\begin{abstract}
A recent study proposed the concept of interfaith spirituality (IFS) that included direct relation with the creator, asceticism, unity of existence, meditation, and divine love, and introduced a measure for it based on an Egyptian sample. The current study utilized five data sets (Egyptians $(\mathrm{N}=490)$, Turkish $(\mathrm{N}=420)$, Kuwaitis $(\mathrm{N}=300)$, Syrians/Palestinians $(\mathrm{N}=179)$, and the UK $(\mathrm{N}=177))$ participants in a combined multi-national sample $(\mathrm{N}=1566)$ to test the invariance of the found unitary second-order factor with four first-order factors of interfaith spirituality across nationalities, religious groups, and gender. The goal also was to test its psychometrics in the new multi-national sample. Confirmatory factor analysis provided evidence for the proposed structure found in the previous study. Multigroup analyses provided evidence of the strong to strict invariance of the IFS structure across national groups, religious groups (Christians and Muslims), and genders. The measure had a high alpha reliability of .97 . The 4 items short form of the scale had an alpha of .83. It had good convergent and divergent and predictive validity. It was correlated with religiosity, posttraumatic growth, identity salience, and emotion regulation. It was negatively correlated with internalizing, externalizing, and thought disorders as well as with poor physical health. Further, using step-wise regression analysis, the measure proved to have strong incremental validity, as IFS contributed the highest variance in internalizing, externalizing, and thought disorders reduction, above and beyond the contribution of emotion regulation, religiosity, and will-to exist, live,
\end{abstract}


and survive.

\section{Keywords}

Interfaith Spirituality, Religiosity, Internalizing Disorders, Externalizing

Disorders, Thought Disorders, Posttraumatic Growth

\section{Measuring Interfaith Spirituality Scale: Cross-Cultural Validation and Invariance}

While researchers cautioned against viewing spirituality and religiousness as incompatible, they found that they represent different ways and levels of thinking about similar ultimate realities (e.g., Hill et al., 2000). Religiousness manifests itself more in external and institutional rituals of devotion or organized worship while spirituality focuses more upon an inner state of being and places the emphasis upon the individual, the personal, and the subjective existential meaning. Such soft distinction is particularly important when discussing, empirically, the potential existence of a moderate association between spirituality, and religion, as the person can be religious and spiritual in his/her way, at the same time. This delicate overlap between religion and spirituality made it difficult to develop a refined comprehensive measure of interfaith spirituality (IFS). A recent study tried to fill this gap and proposed the concept of interfaith spirituality (IFS). The IFS includes the personal heuristics that people who believe in the existence of a sacred creating force, regardless of their different belief systems, use to make sense of humans' finite existence. Such heuristics are based on beliefs concerning the fundamental nature of human existence and involve the belief in a sacred higher power and the ability of self-transcendence (Kira et al., 2021c). IFS included common and core spiritual themes that characterized the different spiritual systems related to different faiths. The recent attempt to define and measure these core spiritual themes identified five structural components: direct connection with the creating force, asceticism, meditation, divine love, and unity of existence. The analysis in an Egyptian sample excluded the unity of existence dimension and found robust psychometrics for the four remaining components that clustered in a second-order factor (Kira et al., 2021c).

The IFS structure was strictly invariant between Christians and Muslims and between genders. However, there is no evidence of the proposed IFS structure or its invariance across the different national groups and Western and non-Western cultures.

There are various variables (e.g., identity salience, physical health, mental health, emotion regulation, and PTG), that are associated positively or negatively with spirituality and provide a robust way to check the convergent, divergent, and predictive validity of IFS. Spiritual identity can be a personal identity that may include collective identity components (Templeton \& Eccles, 2006). There is a variety of ways that spiritual identity provides a sense of continuity as well as 
a domain for adult developmental change (Kiesling et al., 2008). Negotiating a spiritual identity may mean dealing with a conflict between overlapping collective identities. Aspects of identity development were found to mediate the relationship between certain aspects of spirituality (spiritual transcendence, spiritual search, and spiritual function) and certain maladjustment variables (existential anxiety, identity distress, and internalizing symptoms) (Li \& Berman, 2019).

Further, spirituality is tied to better physical health and adequate emotion regulation. The effects of spirituality (e.g., meditation, self-transcendence) on health are thought to be mediated primarily via the effects of emotion regulation on the inflammatory processes underlying chronic illnesses Spirituality is associated with emotion regulation (Aldwin et al., 2014). Measures of spirituality were more strongly linked to biomarkers, including blood pressure, cardiac reactivity, immune factors, and disease progression.

The research provides evidence on the negative association of spirituality and psychopathology (e.g., Koenig, 2009). There is evidence of the negative association of spirituality and externalizing disorders (Holmes \& Kim-Spoon, 2016; Mattis \& Mattis, 2011), mood, and internalizing disorders (e.g., Braam, 2009). There is evidence that spirituality is an effective coping strategy with existential threats (e.g., COVID-19), and a default coping strategy when other coping strategies such as social support, resilience, will to exist, live and survive fail to deal with existential continuous or prolonged traumatic stress (Kira et al., in press).

Spirituality can be a positive resource for posttraumatic growth (PTG) (Pargament et al., 2006). The literature has shown that individuals with more well-developed, or stronger spiritual beliefs and practices, did evidence significantly more posttraumatic growth than individuals with less developed spiritual beliefs and practices. PTG tends to be higher in more spiritual people (Shaw et al., 2005). Several empirical studies have shown a positive relationship between spirituality and PTG (Danhauer et al., 2013).

The goal of the current study is to check the proposed IFS scale structures found in a previous study (Kira et al., 2021c) and their invariance and psychometrics across different cultures and national groups and provide further cross-cultural evidence of its structural, convergence, divergence, predictive and incremental validity.

\section{Research Hypotheses}

Hypothesis 1: IFS structure found in the previous study that consists of second-order unitary factor and four first-order factors (direct connection with the creator, asceticism, meditation, and divine love) will replicate in the multi-national sample. This will confirm its cross-national structural validity.

Hypothesis 2: The replicated structure of IFS will be strongly or strictly invariant across genders, Christians and Muslims, and the different national groups.

Hypothesis 3: The measure IFS will show good psychometrics, including in- 
ternal consistency, good convergent, divergent and predictive validity. IFS will be associated positively with PTG, emotion regulation, and identity salience, and negatively associated with internalizing, externalizing, and thought disorders, as well as with poor health.

Hypothesis 4: The IFS will demonstrate incremental validity by contributing significant independent variance in predicting lower scores on internalizing, externalizing, and thought disorders above and beyond the effects of religiosity, emotion regulation, and will-to-exist-live- and survive.

\section{Methods}

\subsection{Procedures}

We used five datasets that were collected in a wider research project that included an IFS measure as well as other measures. The data sets included participants from Egypt, Turkey, Kuwait, Syrians and Palestinians, and the UK. The combined data set represented different cultures, different levels of exposure to cumulative adversities, different age groups (adolescents and adults), different religious affiliations, and Western and non-Western cultures. The study was approved by the IRB of both Fayoum University, Egypt, and İstanbul Medeniyet University, Istanbul, Turkey, as a cross-cultural study.

\subsection{Participants}

Participants $(\mathrm{N}=1566)$ included five subsamples from different five countries: Egypt $(\mathrm{N}=490)$, Turkey $(\mathrm{N}=420)$, Kuwait $(\mathrm{N}=300)$, the UK $(\mathrm{N}=177)$, and Syrians/ Palestinians $(\mathrm{N}=179)$. It is worth noting that all participants in the Kuwaiti subsample were Kuwaiti citizens, from the city of Kuwait. Most of the residents of Kuwait are non-Kuwaiti citizens. Further, it is worth noting that the majority of the Syrian/ Palestinian sub-sample (86.6\%) were Syrians. The rest were mostly Syrian Palestinians who lived mostly in Syria. Among Syrians, $77.7 \%$ lived in Turkey as refugees who suffered severe traumas, and even those who lived in Syria were mostly internally displaced and were still going through the horror of the complicated Syrian civil war and different type III continuous traumatic stress (Al-Ibraheem, Kira, Aljakoub, \& Al-Ibraheem, 2017; Kira, 2001; Kira, 2021a; Kira 2021b; Kira et al., 2008; Kira et al., 2017). Table 1 includes the details of the demographic information of each of the five subsamples and the combined sample.

\subsection{Measures}

Note: All measures, in the Turkish study, were professionally translated and back-translated to Turkish. For the Arabic Language, the measures were previously translated and back-translated and were used in the previous research (Kira et al., 2021c).

Interfaith Spirituality Scale (IFS) (23 items) (Kira et al., 2021c, Kira et al., 2021b). It was originally five subscales: Direct Relations with the Creator, Asceticism, 
I. Kira et al.

Table 1. The detailed demographics of each of the five sub-samples and the combined sample.

\begin{tabular}{|c|c|c|c|c|c|c|}
\hline variable & Egypt $(\mathrm{N}=490)$ & Turkey $(\mathrm{N}=420)$ & Kuwait $(\mathrm{N}=300)$ & Syrians $(\mathrm{N}=179)$ & $\mathrm{UK}(\mathrm{N}=177)$ & $\begin{array}{l}\text { The Combined } \\
\text { Sample } \\
(\mathrm{N}=1566)\end{array}$ \\
\hline Age & $\begin{array}{l}\text { Age ranged from } \\
14 \text { to } 75, \text { Mean }= \\
26.03, \mathrm{SD}=10.90 \\
20.4 \% \text { adolescents. }\end{array}$ & $\begin{array}{l}\text { Age ranged between } \\
15 \text { and } 64(\mathrm{M}= \\
23.20, \mathrm{SD}=8.68) \\
\text { from which } 18.9 \% \\
\text { were adolescents }\end{array}$ & $\begin{array}{l}\text { age ranged from } 15 \\
-50(\mathrm{M}=26.37 \\
\mathrm{SD}=8.50), \text { from } \\
\text { which } 18.7 \% \text { were } \\
\text { adolescents }\end{array}$ & $\begin{array}{l}\text { Age ranges between } \\
19 \text { and } 54(\mathrm{M}=28.7 \\
\mathrm{SD}=6.16)\end{array}$ & $\begin{array}{l}\text { Age ranged } \\
\text { between } 18 \text { and } \\
40, M=25.89, \\
\text { and } S D=5.66\end{array}$ & $\begin{array}{l}\text { Age ranged } \\
\text { between } 14 \text { and } 75 \text {, } \\
\mathrm{M}=25.63, \mathrm{SD}= \\
9.02,14.1 \% \\
\text { adolescents }\end{array}$ \\
\hline Gender & 41.4 males & $72.4 \%$ males. & $39 \%$ males & $62.6 \%$ males & $60.7 \%$ females & $51.5 \%$ Males \\
\hline Religion & $\begin{array}{l}49.6 \% \text { Muslims } \\
\text { and } 50.4 \%\end{array}$ & $\begin{array}{l}94.3 \% \text { were Muslims } \\
\text { and the balance was } \\
\text { from other religious } \\
\text { affiliations. }\end{array}$ & $\begin{array}{l}99.7 \% \\
\text { Muslims, .3\% } \\
\text { Christians }\end{array}$ & $\begin{array}{l}90.5 \% \text { were } \\
\text { Muslims, .6\% Ismaili } \\
\text { Muslim, } 2.2 \% \\
\text { Christians, } 2.2 \% \\
\text { atheists, .6\% agonists, } \\
2.2 \% \text { identified with } \\
\text { no religion, and .6\% } \\
\text { identified themselves } \\
\text { as humanists }\end{array}$ & $\begin{array}{l}24.2 \% \\
\text { Christians, .6\% } \\
\text { Jewish, } 4.5 \% \\
\text { other religions, } \\
\text { while } 70.8 \% \text { with } \\
\text { no religious } \\
\text { affiliation. }\end{array}$ & $\begin{array}{l}\text { 70.5\% Muslims, } \\
18.9 \% \text { Christians, } \\
2.3 \% \text { atheists and } \\
\text { agnostics, } 8.4 \% \\
\text { non-religious }\end{array}$ \\
\hline Education & $\begin{array}{l}7.9 \% \text { elementary } \\
\text { level, } 1.8 \% \text { middle } \\
\text { school level, } 27.3 \% \\
\text { high school level, } \\
51.8 \% \text { college level, } \\
\text { and } 11 \% \text { graduate } \\
\text { studies level }\end{array}$ & $\begin{array}{l}\text { 5.9\% elementary, } \\
2.9 \% \text { middle school, } \\
17.5 \% \text { high school, } \\
71.7 \% \text { college, and } \\
1.9 \% \text { graduate lvels }\end{array}$ & $\begin{array}{l}4.7 \% \text { elementary } \\
\text { school, } 20.6 \% \text { high } \\
\text { school, } 72.7 \% \\
\text { college and } 2 \% \\
\text { graduate students }\end{array}$ & $\begin{array}{l}.6 \% \text { was elementary } \\
\text { school, .6\% middle } \\
\text { school, } 8.4 \% \text { high } \\
\text { school, } 74.9 \% \\
\text { undergraduate } \\
\text { degree, and } 15.6 \% \\
\text { have graduate degree. }\end{array}$ & $\begin{array}{l}21.3 \% \text { had a high } \\
\text { school, } 57.3 \% \\
\text { had an } \\
\text { undergraduate } \\
\text { degree, and } \\
21.3 \% \text { had a } \\
\text { postgraduate } \\
\text { degree }\end{array}$ & $\begin{array}{l}\text { 14.4\% elementary } \\
\text { level, } 4.8 \% \text { middle } \\
\text { school level, } 16.8 \% \\
\text { high school level, } \\
57.9 \% \text { college } \\
\text { level, and } 6.1 \% \\
\text { have a graduate } \\
\text { degree }\end{array}$ \\
\hline $\begin{array}{l}\text { Marital } \\
\text { Status }\end{array}$ & $\begin{array}{l}28.6 \% \text { married, } \\
68.8 \% \text { single, } 1.6 \% \\
\text { widowed, } .4 \% \\
\text { divorced, } .06 \% \\
\text { other }\end{array}$ & $\begin{array}{l}15.5 \% \text { were married, } \\
82.6 \% \text { were single } \\
\text { and } 1.9 \% \text { other } \\
\text { marital statuses }\end{array}$ & $\begin{array}{l}35 \% \text { married, } \\
60.3 \% \text { singles, } 3 \% \\
\text { divorced, and } 1.7 \% \\
\text { other. }\end{array}$ & $\begin{array}{l}25.7 \% \text { were married, } \\
70.9 \% \text { single, } 2.8 \% \\
\text { divorced and .6\% } \\
\text { widowed? }\end{array}$ & $\begin{array}{l}14.6 \% \text { were } \\
\text { married, } 74.2 \% \\
\text { were single, } 1.7 \% \\
\text { was divorced, } \\
\text { and } 9.6 \% \text { had } \\
\text { other marital } \\
\text { statuses. }\end{array}$ & $\begin{array}{l}24.4 \% \text { married, } \\
71.8 \% \text { single, } 1 \% \\
\text { widowed, } 1.3 \% \\
\text { divorced, } 1.5 \% \\
\text { other }\end{array}$ \\
\hline Employme & $\begin{array}{l}64.5 \% \text { Students, } \\
12.9 \% \text { Employees, } \\
3.4 \% \text { professionals, } \\
3.1 \% \text { workers, } 2.4 \% \\
\text { merchants, } 1.4 \% \\
\text { retired, and } 12.2 \% \\
\text { others }\end{array}$ & $\begin{array}{l}75.1 \% \text { students, } 9.2 \% \\
\text { workers, } 2 \% \\
\text { employees, } .4 \% \\
\text { professionals, } 2.9 \% \\
\text { retire, and } 9.9 \% \\
\text { other }\end{array}$ & $\begin{array}{l}55.3 \% \text { students, } \\
35.7 \% \text { employees, } \\
1.3 \% \text { professionals, } \\
4 \% \text { retired, and } \\
3.7 \% \text { others. }\end{array}$ & $\begin{array}{l}27.4 \% \text { students, } \\
18.4 \% \text { are } \\
\text { unemployed, } 43 \% \text { are } \\
\text { employees, } 3.4 \% \\
\text { merchants, } 2.2 \% \\
\text { professionals, } 1.7 \% \\
\text { workers, } .6 \% \text { retired, } \\
\text { and } 3.4 \% \text { others }\end{array}$ & $\begin{array}{l}48.9 \% \text { were } \\
\text { college students, } \\
39.3 \% \text { were } \\
\text { employees, } 6.2 \% \\
\text { were } \\
\text { professionals, } \\
\text { and } 5.6 \% \text { were } \\
\text { others. }\end{array}$ & $\begin{array}{l}59.5 \% \text { students, } \\
17.6 \% \text { employees, } \\
8.5 \% \text { workers, } \\
1.2 \% \text { merchants, } \\
2.9 \% \text { professionals, } \\
2.1 \% \text { retired, } 8.2 \% \\
\text { other }\end{array}$ \\
\hline $\begin{array}{l}\text { Socio- } \\
\text { Economic- } \\
\text { Status } \\
\text { (poverty) }\end{array}$ & $\begin{array}{l}1 \% \text { very low, } 2 \% \\
\text { low, } 75.1 \% \text { in the } \\
\text { middle, } 18.2 \% \\
\text { high, } 3.7 \% \text { very } \\
\text { high }\end{array}$ & $\begin{array}{l}.5 \% \text { very low, } 6.5 \% \\
\text { low, } 84.8 \% \text { in the } \\
\text { middle, } 6.5 \% \text { high, } \\
1.7 \% \text { very high }\end{array}$ & $\begin{array}{l}0.0 \% \text { very low, } .7 \% \\
\text { low, } 77 \% \text { in the } \\
\text { middle, } 18.3 \% \\
\text { high, } 4 \% \text { very high }\end{array}$ & $\begin{array}{l}25.7 \% \text { very low, } 33 \% \\
\text { low, } 22.9 \% \text { in the } \\
\text { middle, } 11.2 \% \text { high, } \\
7.3 \% \text { very high }\end{array}$ & $\begin{array}{l}1.7 \% \text { very low, } \\
20.3 \% \text { low, } 70.6 \% \\
\text { in the middle, } \\
7.3 \% \text { high, } 0.0 \% \\
\text { very high }\end{array}$ & $\begin{array}{l}3.6 \% \text { very low, } \\
8.6 \% \text { low, } 71.5 \% \text { in } \\
\text { the middle, } 13.1 \% \\
\text { high, } 3.2 \% \text { very } \\
\text { high }\end{array}$ \\
\hline
\end{tabular}

Divine Love and Meditation, and Unity of Existence. However, the Unity of Existence was omitted eventually as it did load only on two items. For each item, each participant was asked to indicate to what extent each statement is true for 
him/her on a scale from 1 - 4, with (4) Mostly true about me, and (1) Not True about me. The instruction introduced a specific definition of spirituality as "the feeling of a direct relationship with your creator, and your ability to transcend yourself. With 'Creator' means the power that puts everything into existence, as you perceive it.". Analysis indicated that the unity of existence dimension needs more development in subsequent studies. The measure proved to have adequate structural, predictive convergent and divergent validity and validity, and reliability and stability. Its Cronbach alpha in the current data was found to be .97 .

Predictive Variables that we Expect to Converge and Positively Associate with IFS:

The religiosity scale is five items that had been used previously in similar populations (e.g., Kira et al., 2006). It contains items that measure the consistent practice of religion. It includes also items about congregating with persons from the same religion, reading the religion's Holy Book, and giving to religious charities. The measure had Cronbach's $\alpha=.70$ in the present study. We assume that religiosity converges and associates positively with IFS.

The will to Exist, Live and Survive (WTELS) measure (Kira et al., 2021d; Kira et al., 2020b; Kira et al., 2021a, Kira et al., 2020a). The measure has six items focused on the different aspects of will to exist, live, survive and thrive. It includes items such as "I am motivated by a drive to live"; "My will to exist and survive adversity is generally". Each item was scored on five points scale: 4 . Very strong. 3. Strong, 2, Neutral, 1. Drained/depleted, 0 extremely depleted. I have no will to survive. Exploratory and confirmatory factor analyses found that the measure has a one-factor structure. The measure's one-factor structure was strictly invariant across gender, cultural and religious groups. The test-retest reliability coefficient ( 4 weeks interval) on a sample $(\mathrm{N}=34)$ was found to be .82 . It was found to have good convergent, divergent and predictive validity. WTELS predicted lower mental health symptoms, and existential anxiety and higher self-esteem, emotion regulation (reappraisal), and posttraumatic growth (Kira et al., 2020b). The Cronbach's reliability of the scale obtained with the present sample was ( $\alpha$ $=.82$ ). We assume that WTELS converges and associates positively with IFS.

Emotion Regulation Questionnaire: The ERQ (Gross \& John, 2003) comprises ten items assessing the reappraisal (6 items) and suppression (4 items). The questionnaire measures two emotion regulation strategies: Reappraisal and Suppression. An example of the items of the Reappraisal subscale is: (I control my emotions by changing the way I think about the situation I am in). An example of items of Suppression subscale is: (I control my emotions by not expressing them). Items are rated on a 7-point Likert-type response scale. Higher scores on each scale indicate greater use of the corresponding ER strategy. The ERQ has been reported to have adequate internal consistency ( $\alpha=.79$ for Reappraisal, and .73 for Suppression) and 3-month test-retest reliability $(r=.69$ for both scales), as well as sound convergent and discriminant validity with both younger and older adults (Gross \& John, 2003; John \& Gross, 2004). The measure was previously scientifically translated into Arabic and found to have good psycho- 
metrics. In the current data, Reappraisal has $(\alpha=.89)$, and Suppression has ( $\alpha$ $=.78)$. We assume that at least the Reappraisal emotion regulation strategy converges and associates positively with IFS.

The Post-Traumatic Growth Inventory (PTGI); (Tedeschi \& Calhoun, 1996) assesses perceived positive life changes (e.g., enhanced relationships, greater life appreciation) following stressful experiences. In completing the 21 items, participants respond on a scale from 0 (I did not experience this change as a result of my experience) to 5 (I experienced this change to a very significant degree). The measure includes five subscales: relating to others, new possibilities, personal strength, spiritual change, and appreciation of life. In a validation study, Tedeschi and Calhoun (1996) found the internal consistency (alpha) of the total PTGI to be .90 and the test-retest reliability coefficient to be .71. The measure also appears to have sound psychometric properties in the Arabic language version (Kira et al., 2012a; Kira et al., 2013), with an alpha of .96 for the main measure. In the current data, the scale had an alpha of .90. Alpha coefficients ranged between .83 and .70 for its five subscales. We assume that PTG converges and associates positively with IFS.

Identity Salience Scale (Kira, Templin et al., 2011; Kira, Alawneh et al., 2011) is a ten-item scale that was developed in two studies on 880 Palestinian adolescents. Identity salience, or dormancy, refers to the status of one group's identity in their nested hierarchy, whether it is central or peripheral. It includes questions like "I feel personally threatened by hate crimes committed against myself or the members of my race, religion, culture or ethnic group or another group of my belonging." Another example is "Sometimes I wish to die or kill somebody or myself before my ethnic, or religion or nation or any other group of my belonging is harmed, eliminated or subjugated." The response indicates how much he or she disagrees or agrees on a scale from 1 to $7(1=$ entirely disagree; $7=$ absolutely agree). Higher scores indicate greater collective identity salience; lower scores highlight more personal identity salience. There are follow-up questions about the relative importance of each group. Exploratory and confirmatory factor analysis found support for two subscales: Identity Commitment and Identity Militancy. Internal consistency reliability (alpha) for the measure was .80 for adolescents (and .81 in another adult Palestinian sample; $\mathrm{N}=132$ ), with alphas of .74 for the Commitment and .75 for the Militancy (ready to die for your group) subscales (Kira et al., 2013). Test-retest reliability after three weeks was .76. The measure was found to have good predictive validity. Higher personal and collective identity traumas predicted higher collective identity salience. Higher Identity Salience predicted higher Existential Annihilation Anxiety and mortality salience (Kira et al., 2017b; Kira et al., 2019a; Kira et al., 2018). In the current analysis, we considered identity commitment as a measure for collective identity salience, and Militancy as one of the coping strategies for collective identity trauma of oppression, through different forms of active resistance and readiness to sacrifice or die for the group. The scale's alpha was .88 in current data. Identity Salience (commitment) subscale had an alpha of .80, and 
Identity Militancy had an alpha of .87 in the present data.

Diverging (Predictive) Variables with Expected Negative Association with IFS:

Psychopathology Measure (Kira et al., 2017a) Reconstructed GAIN Short Screener (GAIN-SS) (Dennis et al., 2006) is a screener, that identifies clients (adults and adolescents) who are likely to have Internalizing, Externalizing, and Thought disorders. The participant is asked to indicate if the behavior (or feeling) happened in the past month (scored 4), or happened in the last 2 - 3 months (scored 3), or in the last 3 - 12 months (scored 2), or the last year or more (scored 1), or never happened (scored 0). High scores indicate potentially higher symptoms in these areas. The original measure included three parts: Internalizing, Externalizing, and Substance Abuse sections. The measure was reconstructed to include a section for Psychoticism and Dissociation, adding items from the psychoticism/dissociation subscale of cumulative trauma disorder scale (Kira et al., 2012c). Further, items were added to internalizing that are related to PTSD symptoms. The original version did not include different PTSD symptoms. The goal of its adaptation was to include the three basic components of psychopathology found in research: Internalizing, Externalizing, and Thought Disorder (psychoticism) (e.g. Caspi et al., 2014; Laceulle et al., 2015). The current reconstructed measure includes 20 items. Exploratory and Confirmatory Factor Analysis of the reconstructed measure in different data in Egypt and Poland yielded the three factors: Internalizing, Externalizing, and Thought Disorders. Test-retest using an independent sample of 35 males with four weeks interval yielded excellent stability coefficients ( .970 for Internalizing, .908 for Externalizing, 915 for Thought Disorder subscale. The measure includes items on suicidality as well as substance abuse. In the current study, alpha reliability for Internalizing was $.84, .88$ for Externalizing and addiction, and .93 for Thought Disorders. The total scale of Psychopathology has an alpha of .90 in current data. We assume that Psychopathology, and its subscales, diverges and associates negatively with IFS.

Poor Physical Health Scale (13 items, modified; Kira et al., 2001). The measure was developed and used in previous studies on Iraqi refugees and Palestinians. It includes a question about global self-rated health on a 5-point Likert-type scale. It included questions on how health problems affected the participant's personal relations, memory, and ability to work. It also includes a checklist of specific acute and chronic physical health problems, based on the taxonomy of health problems of ICD-9-CM codes for selected general medical conditions such as neurological and blood pressure disorders and digestive system, musculoskeletal, and endocrine illnesses. The higher the score, the worse is the participant's health condition. The high score on the measure was found to be highly associated with PTSD, CTD (complex PTSD), and older age (Kira et al., 2006). It was found, in different studies, to have adequate reliability that ranged between 70 and 85 (e.g., Kira et al., 2019b). The scale alpha reliability in current data is .753.

Demographic Variables. In addition to the independent and outcome va- 
riables measures, demographic information was collected and included age, gender, marital status, education, religion, and income. Yearly income was converted to a score from 1 to 5 , with $1=0-500 \$$, and $5=$ more than $5000 \$$ a year.

\section{Statistical Analysis}

The data were analyzed utilizing IBM-SPSS 22 and AMOS 22. We used Cohen's (1992) criteria and recommendations, and advanced software to determine the sample size that achieves medium population effect size at power $=.80$ for $\alpha$ $=.05$ for the number of variables. We calculated frequencies and basic descriptions. We conducted a zero-order correlation between the primary variables. We used religiosity to assess the criterion validity of IFS. In keeping with the view that spirituality and religion are overlapping constructs, it was hypothesized that the IFS would significantly correlate with religiosity. However, in tandem with the assumption that spirituality and religion are distinct systems, it was also expected that a relatively high correlation (above .50) between them would not exist.

To assess concurrent and divergent and predictive validities-the extent to which a measure correlates positively or negatively with other theoretically related variables (Monod et al., 2011), we tested the correlation between IFS, "will-to exist, live and survive", emotion regulation and PTG to assess its concurrent validity. We tested its relationship with PTSD, EAA, depression, psychopathology, and psychopathology's three components (internalizing, externalizing, and thought disorder) to assess its divergent validity. Further, we investigated the reliability of the scale with Cronbach's alpha.

To measure the structural validity of IFS four dimensions. We conducted confirmatory factor analysis (CFA) using the previously identified model of the four first-order factors and the second-order unitary factor found in the previous research to test its model fit in the new multinational data. Following Hooper, Coughlan, Mullen, 2008, recommendations, the criteria for good model fit were a non-significant $\left(\chi^{2}\right),\left(\chi^{2} /\right.$ d.f. $\left.<2\right)$, comparative fit index $(\mathrm{CFI})$ values $>.90$, and root-mean-square error of approximation (RMSEA) values $<.08$. Further, we set a conservative threshold by accepting only items that loaded .50 or above on any factor.

Additionally, to assess whether the measurement model of the scale and its structural components are invariant (reliable and stable) across genders, religious affiliations (Christian and Muslims), and nationalities (Egypt, Turkey, Kuwait, Syria, and the UK). We conducted a multi-group invariance analysis (Meredith \& Teresi, 2006; Meredith, 1993). Four nested models were tested sequentially: a configural invariance model, a metric invariance model, a scalar invariance model, and a strict invariance model. In the configural model, (i.e., identical form), the parameters are all freely estimated across groups. Configural invariance assumes that the same theoretical model holds across all relevant groups (e.g., van de Schoot, Lugtig, \& Hox, 2012). In the metric model (i.e., weak 
or partial invariance), the parameters are constrained to be identical across groups. In the scalar model or "strong invariance," variables and paths variances are set to be equal across groups. Lastly, the strict model "strict invariance" additionally constrains the residuals to be the same across the three groups. Although there is broad acceptance of the steps for testing measurement invariance, the criteria for evaluating the invariance of the models at each level are not as clear. Byrne, Shavelson, \& Muthén, 1989, have argued that invariance can be established when two indicators are invariant. According to Chen (2007), the null hypothesis of invariance should not be rejected when changes in CFI are less than or equal to .01 and in RMSEA are less than or equal to .015.

Further, to test the incremental validity of IFS, as well as its short form, in predicting lower internalizing, externalizing, and thought disorders over and above the effects of emotion regulation, religiosity, and "will to exist-live and survive", we conducted a series of stepwise multiple regressions. In the first step, and further subsequent steps, we entered gender, age, and reappraisal (emotion regulation), in the second step we added "WTELS", in the third step we added religiosity, and in the fourth step, we added either IFS or its short form IFS-S-4. Marital status, income, and education were not significantly correlated with IFS (r's $=.03, .03$, and .05 consecutively), so we did not enter them in the first step.

\section{Results}

Descriptive data: For the total sample the IFS Mean was 77.02 with SD of 21.41, Skewness $=-1.22(\mathrm{SE}=.06)$, Kurtosis $=.618(\mathrm{SD}=.13)$. IFS Mean for Egypt was 85.03 with SD of 11.19. IFS Mean for Kuwait was 86.41 with SD of 11.11, IFS for Turkey was 75.78 with SD 16.87. IFS Mean for Syrians was 81.55 with SD of 19.84. For the UK, IFS Mean was 37.31 with SD of 17.17.

Confirmatory factor analysis results (Construct Validity): The second-order factor with four first-order factors model found in the previous study (Kira et al., 2019) was tested in the new multi-nationals sample found to have a good fit with the data (Chi-Square $=1955.653$, d.f $=218, p=.001, C F I=.946$, and $R M S E A$ $=.076)$. All items were significantly and highly loaded (.50 or above) as well as the four first-order four factors. Chi-Square is high and insignificant, Chi-Square statistic is sensitive to sample size which means it nearly always rejects the model when a large sample is used (Bentler \& Bonnet, 1980). However, the other fit indices ( $C F I$ and RMSEA) indicated an acceptable fit. Figure 1 presents the results.

Measurement Invariance of the Interfaith Spirituality Scale: Testing the invariance of the IFS measurement model (its reliability and stability) across genders, religious groups of Muslims and Christians, and across the five national groups, The model was found to be strictly invariance between genders and between the two religious groups, and strongly (not strictly) invariant across the five national groups, Table 2 presents these results. 


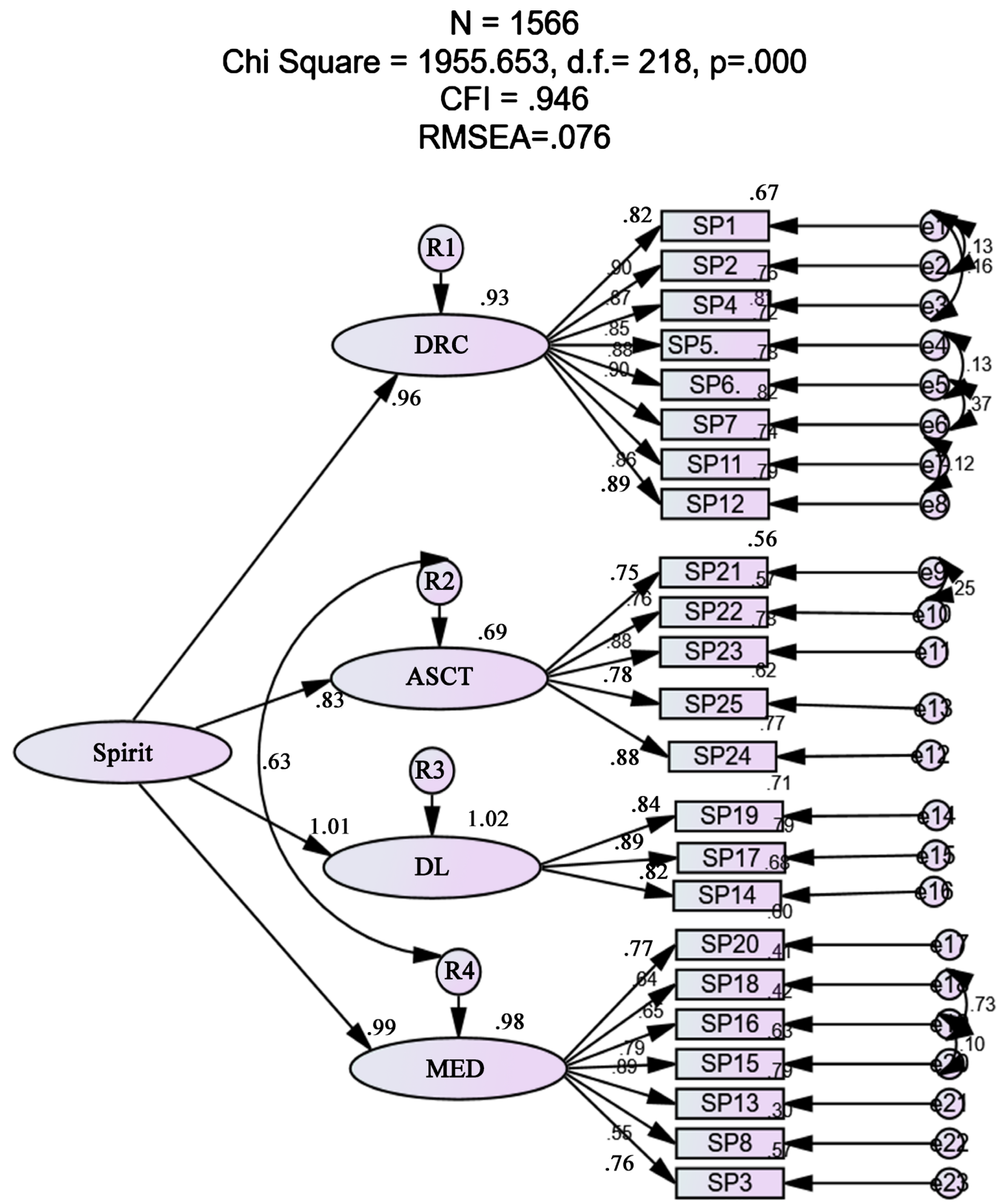

Note: Spirit $=$ Interfaith Spirituality, Med $=$ Meditation, $\mathrm{DL}=$ Divine Love, ASCT $=$ Asceticism, $\mathrm{DRC}=$ Direct relation with the creator.

Figure 1. Confirmatory factor analysis: The second-order unitary factor of IFS with the four first-order factors: The direct relationship with the creator, asceticism, divine love, and meditation: The factor loadings of the items on the second-order factors (DRC, ASCT, DL, and MED), and the factor loadings of these second-order factors on the first-order factor (Spirit), also the Beta weight of each factor. For the content of the items see Appendix.

\section{Reliability and Stability}

Cronbach alpha for IFS (the 23 items version) in the total sample was .973, while in Egypt sub-sample it was .921, in Kuwait subsample it was .923, in the UK sub-sample it was .974, in Turkey subsample, it was .958, and in the Syrians/ Palestinians subsample it was .968 . The 4 items short form of the scale has an 
Table 2. Multi-group invariance fit indicators between the five national groups, Religion groups, and genders.

Multi-group Invariance between national Sub-samples

\begin{tabular}{|c|c|c|c|c|c|c|c|}
\hline & Chi-square & $d f$ & $p$ & chi-square/di & $C F I$ & $R M S E A$ & $I F I$ \\
\hline Unconstrained & 3793.443 & 1090 & .001 & 3.480 & .892 & .040 & .893 \\
\hline Measurement weights & 4159.456 & 1162 & .001 & 3.580 & .885 & .041 & .881 \\
\hline Measurement intercepts & 5897.056 & 1254 & .001 & 4.703 & .882 & .049 & .816 \\
\hline Structural weights & 6059.521 & 1266 & .001 & 4.786 & .809 & .049 & .810 \\
\hline Structural covariance & 6894.899 & 1270 & .001 & 5.429 & .776 & .053 & .777 \\
\hline Structural residuals & 7032.728 & 1290 & .001 & 5.452 & .771 & .053 & .772 \\
\hline Measurement residuals & 10332.540 & 1414 & .001 & 7.307 & .644 & .064 & .644 \\
\hline \multicolumn{8}{|c|}{ Multi-group Invariance between Muslims and Christians } \\
\hline Unconstrained & 2221.310 & 428 & .001 & 5.190 & .915 & .055 & .916 \\
\hline Measurement weights & 2303.992 & 446 & .001 & 5.166 & .912 & .055 & .913 \\
\hline Measurement intercepts & 2533.693 & 469 & .001 & 5.402 & .912 & .056 & .903 \\
\hline Structural weights & 2542.328 & 472 & .001 & 5.386 & .912 & .056 & .902 \\
\hline Structural covariance & 2562.361 & 473 & .001 & 5.417 & .901 & .056 & .901 \\
\hline Structural residuals & 2584.167 & 478 & .001 & 5.406 & .900 & .056 & .901 \\
\hline Measurement residuals & 2856.827 & 513 & .001 & 5.569 & .889 & .057 & .889 \\
\hline \multicolumn{8}{|c|}{ Multi-group Invariance between Genders } \\
\hline Unconstrained & 2378.115 & 428 & .001 & 5.556 & .944 & .055 & .944 \\
\hline Measurement weights & 2402.661 & 446 & .001 & 5.387 & .943 & .054 & .943 \\
\hline Measurement intercepts & 2519.757 & 469 & .001 & 5.373 & .941 & .054 & .941 \\
\hline Structural weights & 2522.560 & 472 & .001 & 5.344 & .941 & .054 & .941 \\
\hline Structural covariance & 2532.553 & 473 & .001 & 5.354 & .940 & .054 & .940 \\
\hline Structural residuals & 2565.347 & 478 & .001 & 5.367 & .940 & .054 & .940 \\
\hline Measurement residuals & 2864.495 & 513 & .001 & 5.584 & .934 & .055 & .934 \\
\hline
\end{tabular}

alpha of .828. Previous research on the Egyptian sample reported test-retest stability of .72 (Kira et al., 2019).

Correlational results (Criterion, convergent and divergent validity): IFS was moderately correlated with religiosity, negatively correlated with poor health, internalizing, externalizing, and thought disorders. It was positively correlated with PTG, emotion regulation (reappraisal and suppression), and identity salience. Further, it was highly correlated with its short form (.92) (see Table 3). Similar results were found for the four subscales of the measure (Table 4).

Incremental validity results: In Model 4 (when we added IFS) IFS explained the highest variance in internalizing disorders reduction above what WTELS, 
emotion regulation, and religiosity contribution explained (Table 5). Similar results were found for its added contribution to externalizing disorders (Table 6) and thought disorders reduction (Table 7). The results provided evidence of

Table 3. Zero-order correlations between IFS, its short form (IFS-S-4), and the convergent and divergent variables. Alpha reliability of each scale is inserted in the diagonal.

\begin{tabular}{|c|c|c|c|c|c|c|c|c|c|c|c|}
\hline & 1 & 2 & 3 & 4 & 5 & 6 & 7 & 8 & 9 & 10 & 11 \\
\hline 1. IFS Scale & .97 & & & & & & & & & & \\
\hline 2. IFS-4 & $.92^{\star \star \star}$ & .83 & & & & & & & & & \\
\hline 3. Religiosity & $.50^{\star * *}$ & $.38^{\star * *}$ & .70 & & & & & & & & \\
\hline 4. PTGI & $18^{* * *}$ & $.15^{\star * \star}$ & $.13^{* * *}$ & .90 & & & & & & & \\
\hline 5. Reappraisal & $.08^{\star \star \star}$ & $.08^{\star * *}$ & $.11^{\star * \star}$ & $.20^{\star * *}$ & .89 & & & & & & \\
\hline 6. Suppression & $.09^{\star * *}$ & $.10^{* *}$ & .03 & .05 & $.36^{\star * *}$ & .78 & & & & & \\
\hline 7. Identity Salience & $.31^{\star * *}$ & $.17^{\star * *}$ & $.37^{* * *}$ & $.19^{\star * *}$ & $.11^{\star * *}$ & .02 & .88 & & & & \\
\hline 8. Internalizing & $-.38^{\star * *}$ & $-.34^{\star \star \star}$ & $-.27^{\star * *}$ & -.01 & $-.06^{\star}$ & .01 & $-.18^{\star * \star}$ & .85 & & & \\
\hline 9. Externalizing & $-.44^{* * *}$ & $-.37^{\star \star \star}$ & $-.30^{\star * *}$ & $-.09^{\star *}$ & $-.17^{\star \star \star *}$ & $-.06^{\star}$ & $-.30^{\star * *}$ & $.47^{\star * *}$ & .88 & & \\
\hline 10. Thought Disorders & $-.25^{\star * *}$ & $-.19^{\star * *}$ & $-.20^{\star * *}$ & .03 & $-.11^{\star * *}$ & .03 & $-.14^{* * *}$ & $.56^{\star * *}$ & $.58^{\star * \star}$ & .90 & \\
\hline 11. Poor physical health & $-.18^{\star \star \star}$ & $-.17^{\star * \star}$ & $-.19^{* * *}$ & .02 & -.03 & -.04 & .02 & $.26^{\star * *}$ & $-.12^{\star \star \star}$ & $-.14^{* * *}$ & .75 \\
\hline
\end{tabular}

Note: $+p<.10{ }^{\star} p<.05,{ }^{* *} p<.01,{ }^{* *} p<.001$. Note: IFS = Interfaith Spirituality, IFS-4 + Interfaith Spirituality 4-items short-form scale, $\mathrm{PTGI}=$ Posttraumatic Growth inventory.

Table 4. Zero-order correlations between the four IFS subscales, the IFS-S-4, and convergent and divergent variables.

\begin{tabular}{|c|c|c|c|c|c|}
\hline & $\begin{array}{l}\text { Direct connection } \\
\text { with the creator }\end{array}$ & Asceticism & Meditation & $\begin{array}{l}\text { Divine } \\
\text { love }\end{array}$ & IFS-4 \\
\hline Religiosity & $.55^{\star \star \star}$ & $.50^{\star * \star}$ & $.40^{* * *}$ & $.51^{\star * *}$ & $.38^{\star * *}$ \\
\hline PTGI & $.17^{\star * \star}$ & $.20^{* * *}$ & $.19^{\star * *}$ & $.17^{\star * *}$ & $.15^{\star * *}$ \\
\hline \multicolumn{6}{|l|}{ Emotion Regulation } \\
\hline 1. Reappraisal & $.09^{* * *}$ & $.14^{\star \star \star}$ & $.06^{*}$ & $.09^{\star \star \star}$ & $.08^{\star *}$ \\
\hline 2. Suppression & $.07^{\star *}$ & $.08^{\star * *}$ & $.10^{\star * *}$ & $.08^{* * *}$ & $.11^{* * *}$ \\
\hline Identity Militancy & $.25^{\star \star *}$ & $.26^{\star * *}$ & $.21^{\star \star \star}$ & $.25^{\star * *}$ & $.16^{* * *}$ \\
\hline Identity Salience & $.29^{\star \star *}$ & $.29^{* * *}$ & $.22^{\star \star \star *}$ & $.28^{\star * *}$ & $.17^{\star * \star}$ \\
\hline \multicolumn{6}{|l|}{ Psychopathology } \\
\hline 1. Internalizing & $-.37^{\star \star \star *}$ & $-.29^{\star * *}$ & $-.31^{\star * *}$ & $-.36^{* * *}$ & $-.34^{\star * *}$ \\
\hline 2. Externalizing & $-.45^{\star * \star}$ & $-.35^{\star * \star}$ & $-.35^{\star * \star}$ & $-.45^{\star * *}$ & $-.38^{\star * *}$ \\
\hline 3. Thought Disorders & $-.25^{\star * *}$ & $-.21^{\star * *}$ & $-.19^{* * *}$ & $-.24^{\star * *}$ & $-.19^{* * *}$ \\
\hline $\begin{array}{l}\text { Cumulative Stressors } \\
\text { and Traumas }\end{array}$ & $-.23^{* * *}$ & $-.23^{* * *}$ & $-.19^{* * *}$ & $-.23^{\star * *}$ & $-.23^{\star * *}$ \\
\hline Poor Physical health & $-.19^{* * *}$ & $-.21^{\star * *}$ & $-.15^{\star * *}$ & $-.18^{\star * *}$ & $-.18^{\star * *}$ \\
\hline
\end{tabular}

Note: $+p<.10{ }^{\star} p<.05,{ }^{* *} p<.01,{ }^{* *} p<.001$. Note: IFS-4 + Interfaith Spirituality 4 -items short-form scale, PTGI $=$ Posttraumatic Growth inventory. 
Table 5. Step-wise multiple regression of the incremental contribution of IFS (interfaith spirituality scale) in predicting lower internalizing disorders.

\begin{tabular}{|c|c|c|c|c|c|c|c|c|}
\hline Model & Variables & B & $\begin{array}{l}\text { Std. } \\
\text { Error }\end{array}$ & Beta & $\mathbf{t}$ & $p$ & $\begin{array}{c}\mathrm{R}^{2} \\
\text { (change } \\
\text { in } \mathrm{R}^{2} \text { ) }\end{array}$ & $\begin{array}{c}F \text { for } \\
\text { change } \\
\text { in } R^{2}\end{array}$ \\
\hline \multirow{3}{*}{ Model 1} & Gender & 1.084 & .360 & .078 & 3.010 & .003 & \multirow{3}{*}{.035} & \multirow{3}{*}{$17.177^{\star \star \star}$} \\
\hline & Age & -.143 & .023 & -.159 & -6.114 & .001 & & \\
\hline & Reappraisal & -.070 & .029 & -.062 & -2.407 & .016 & & \\
\hline \multirow{4}{*}{ Model 2} & Gender & 1.346 & .357 & .097 & 3.770 & .001 & \multirow{4}{*}{.029} & \multirow{4}{*}{$43.692^{* * *}$} \\
\hline & Age & -.127 & .023 & -.142 & -5.509 & .001 & & \\
\hline & Reappraisal & -.025 & .029 & -.022 & -.846 & .398 & & \\
\hline & WTELS & -.299 & .045 & -.176 & -6.610 & .001 & & \\
\hline \multirow{5}{*}{ Model 3} & Gender & 1.601 & .343 & .115 & 4.663 & .001 & \multirow{5}{*}{.075} & \multirow{5}{*}{$125.267^{\star * x}$} \\
\hline & Age & -.132 & .022 & -.146 & -5.933 & .001 & & \\
\hline & Reappraisal & .006 & .028 & .005 & .202 & .840 & & \\
\hline & WTELS & -.257 & .044 & -.151 & -5.911 & .001 & & \\
\hline & Religiosity & -.533 & .048 & -.278 & -11.192 & .001 & & \\
\hline \multirow{6}{*}{ Model 4} & Gender & 1.193 & .329 & .086 & 3.631 & .001 & \multirow{6}{*}{.081} & \multirow{6}{*}{$148.238^{\star * *}$} \\
\hline & Age & -.120 & .021 & -.134 & -5.684 & .001 & & \\
\hline & Reappraisal & .019 & .027 & .017 & .698 & .486 & & \\
\hline & WTELS & -.269 & .041 & -.158 & -6.486 & .001 & & \\
\hline & Religiosity & -.202 & .053 & -.106 & -3.830 & .001 & & \\
\hline & IFS & -.125 & .010 & -.334 & -12.175 & .001 & & \\
\hline
\end{tabular}

Note: $+p<.10^{\star} p<.05,{ }^{* *} p<.01,{ }^{* * *} p<.001$.

Table 6. Step-wise multiple regression of the incremental contribution of IFS in predicting lower externalizing disorders.

\begin{tabular}{llccccccc}
\hline Model & Variables & B & $\begin{array}{c}\text { Std. } \\
\text { Error }\end{array}$ & Beta & $\mathbf{t}$ & $\boldsymbol{P}$ & $\begin{array}{c}\mathbf{R}^{2} \\
\text { (change } \\
\left.\text { in } \mathbf{R}^{2}\right)\end{array}$ & $\begin{array}{c}\text { F for } \\
\text { change } \\
\text { in } \mathbf{R}^{2}\end{array}$ \\
\hline \multirow{2}{*}{ Model 1 } & Age & -.058 & .018 & -.083 & -3.249 & .001 & .065 & $32.993^{\star * *}$ \\
& Reappraisal & -.157 & .022 & -.181 & -7.053 & .001 & & \\
\hline \multirow{2}{*}{ Model 2 } & Age & 1.680 & .274 & .158 & 6.136 & .001 & & \\
& Reappraisal & -.154 & .023 & -.179 & -6.766 & .001 & & \\
& WTELS & -.015 & .035 & -.012 & -.437 & .662 & & \\
\hline Model 3 & Gender & 1.924 & .263 & .181 & 7.328 & .001 & .091 & $152.273^{* * *}$ \\
\hline
\end{tabular}


Continued

\begin{tabular}{|c|c|c|c|c|c|c|c|c|}
\hline & Age & -.060 & .017 & -.087 & -3.554 & .001 & & \\
\hline & Reappraisal & -.129 & .022 & -.150 & -5.938 & .001 & & \\
\hline & WTELS & .020 & .033 & .015 & .594 & .553 & & \\
\hline & Religiosity & -.451 & .037 & -.305 & -12.34 & .001 & & \\
\hline \multirow{6}{*}{ Model 4} & Gender & 1.552 & .247 & .146 & 6.274 & .001 & \multirow{6}{*}{.104} & \multirow{6}{*}{$199.181^{\star \star \star}$} \\
\hline & Age & -.051 & .016 & -.074 & -3.206 & .001 & & \\
\hline & Reappraisal & -.119 & .020 & -.137 & -5.805 & .001 & & \\
\hline & WTELS & .009 & .031 & .007 & .297 & .766 & & \\
\hline & Religiosity & -.159 & .040 & -.108 & -3.973 & .001 & & \\
\hline & IFS & -.109 & .008 & -.379 & -14.11 & .001 & & \\
\hline
\end{tabular}

Note: $+p<.10^{\star} p<.05,{ }^{* *} p<.01,{ }^{* * *} p<.001$.

Table 7. Step-wise multiple regression of the incremental contribution of IFS (interfaith spirituality scale) in predicting lower thought disorders.

\begin{tabular}{|c|c|c|c|c|c|c|c|c|}
\hline Model & Variables & B & $\begin{array}{l}\text { Std. } \\
\text { Error }\end{array}$ & Beta & $\mathrm{t}$ & $p$ & $\begin{array}{c}\mathrm{R}^{2} \\
\text { (change } \\
\text { in } \mathrm{R}^{2} \text { ) }\end{array}$ & $\begin{array}{c}\text { F for } \\
\text { change } \\
\text { in } R^{2}\end{array}$ \\
\hline \multirow{3}{*}{ Model 1} & Gender & 1.594 & .323 & .127 & 4.940 & .001 & \multirow{3}{*}{.067} & \multirow{3}{*}{$33.884^{* * *}$} \\
\hline & Age & -.155 & .021 & -.190 & -7.400 & .001 & & \\
\hline & Reappraisal & -.126 & .026 & -.123 & -4.807 & .001 & & \\
\hline \multirow{4}{*}{ Model 2} & Gender & 1.816 & .320 & .144 & 5.672 & .001 & \multirow{4}{*}{.026} & \multirow{4}{*}{$40.928^{* * *}$} \\
\hline & Age & -.142 & .021 & -.173 & -6.828 & .001 & & \\
\hline & Reappraisal & -.086 & .026 & -.084 & -3.244 & .001 & & \\
\hline & WTELS & -.262 & .041 & -.168 & -6.397 & .001 & & \\
\hline \multirow{5}{*}{ Model 3} & Gender & 1.984 & .314 & .158 & 6.313 & .001 & \multirow{5}{*}{.038} & \multirow{5}{*}{$61.596^{* * x}$} \\
\hline & Age & -.145 & .020 & -.177 & -7.116 & .001 & & \\
\hline & Reappraisal & -.067 & .026 & -.066 & -2.564 & .010 & & \\
\hline & WTELS & -.236 & .040 & -.151 & -5.867 & .001 & & \\
\hline & Religiosity & -.343 & .044 & -.197 & -7.848 & .001 & & \\
\hline \multirow{6}{*}{ Model 4} & Gender & 1.774 & .311 & .141 & 5.703 & .001 & \multirow{6}{*}{.027} & \multirow{6}{*}{$44.856^{\star * x}$} \\
\hline & Age & -.139 & .020 & -.170 & -6.933 & .001 & & \\
\hline & Reappraisal & -.059 & .026 & -.058 & -2.312 & .021 & & \\
\hline & WTELS & -.242 & .040 & -.155 & -6.116 & .001 & & \\
\hline & Religiosity & -.169 & .050 & -.097 & -3.371 & .001 & & \\
\hline & IFS & -.065 & .010 & -.192 & -6.697 & .001 & & \\
\hline
\end{tabular}

Note: $+p<.10^{\star} p<.05,{ }^{* *} p<.01,{ }^{* *} p<.001$. 
its incremental independent contribution in significantly lowering mental health disorders and its superiority compared to other variables in this multi-national sample. Similar results were found after adding IFS-S-4 short form in the fourth step.

\section{Conclusion/Discussion}

The study replicated the results of the previous study (Kira et al., 2021c) and provided additional evidence of the IFS conceptualization and measurement and structural invariance across five national groups. IFS structure found in the previous study which consists of second-order unitary factor and four first-order factors (direct connection with the creator, asceticism, meditation, and divine love) was replicated in the current multi-national sample. This confirmed the IFS cross-group and within-group structure and parameter stability. The structure of IFS was strongly or strictly invariant across genders, Christians and Muslims, and the different national groups. Christians in the samples included different denominations (Coptic, Roman Catholic, Anglicans). Muslims, while mostly Sunni, they included some Shiite and Ismaili minorities. Invariance is a key to proving that different data sets come from an underlying population, and the measure can be used and compared equally across these subpopulations. The study highlighted its sound psychometrics cross-culturally. The measure demonstrated good internal consistency, good convergent, divergent and predictive validity. IFS was associated positively with PTG, emotion regulation, and identity salience, and negatively associated with internalizing, externalizing, and thought disorders, as well as with poor health. Further, it highlighted its incremental validity contributing significant effect size (and the relatively highest compared to other variables in the model) in reducing internalizing, externalizing, and thought disorder above and beyond the contribution of emotional regulation, will - to exist, live and survive, and religiosity. IFS and its short form (IFS-S-4) have good psychometrics and can be used in cross-cultural research, mental health clinics, and interfaith spirituality assessment.

Further, current findings have important and practical significance for previous, current, and future research. IFS's highest positive correlation (after religiosity) was with identity salience (.31). Strong identification with ethnic identity is linked to a host of beneficial outcomes and intersects with youths' religious/spiritual identities (Juang \& Syed, 2008; Kira, 2019; Kira et al., 2012b). This is one of the first studies that provided empirical evidence of the strong link between interfaith spirituality and identity.

Emotion regulation, especially reappraisal was associated with IFS especially with its Asceticism subscale. The virtue of patience, for example, which is part of the concept of asceticism is conceptualized as a hybrid personality construct related to effective emotion regulation that is coupled with transcendent narrative identity, found to predict better life outcomes (Schnitker et al., 2017). However, the area of research on the relationship between IFS and emotion regulation is 
almost missing in current literature and there is a need to be addressed more thoroughly in future research.

IFS was positively correlated with PTG. This positive relationship was long observed in empirical research (Shaw et al., 2005). However, researchers of posttraumatic growth consider PTG to consist of two sides, a constructive side reflecting veridical growth, and a deceptive, illusory side (Boals \& Schuler, 2018; Maercker \& Zoellner, 2004). Determining whether self-reported PTG reflects actual or illusory growth is a difficult but vital challenge for PTG researchers. Future research should help determine which side of PTG is associated with IFS.

Further, the findings of current research have significant clinical implications. The findings provided evidence for the significant impact of interfaith spirituality on lowering internalizing, externalizing, and thought disorders solidifying the established research on the relationship between spirituality and mental health (e.g., Koenig, 2009) and providing evidence of the measure predictive and incremental validity. For, example, direct connection with the creator and divine and unconditional love have the highest negative correlation with externalizing disorders (-.45). Such results have important implications for spirituality screening and intervention especially with patients with externalizing disorders.

One of the potential limitations of the current study is that it was conducted in convenient samples that may have limited and biased representation. We recommend more studies that use more representative samples. Another limitation is that the measures we used are based on participants' self-reports, which could be subject to under- or over-reporting of events due to current symptoms, embarrassment, shame, or social desirability. Further, the samples that represent Western cultures were limited to the UK. Including more Western samples, as well as Jewish samples and samples from the Far East (India, China, and Japan) should make the argument of invariance of the model or some of its components across different cultures and religions stronger. Further, while the current study validated the four-factor structure that eliminated the unity of existence factor due to lack of enough items that represent this concept. Future studies may try to check the validity of this fifth eliminated factor.

\section{Conflicts of Interest}

The authors declare no conflicts of interest regarding the publication of this paper.

\section{References}

Aldwin, C. M., Park, C. L., Jeong, Y.-J., \& Nath, R. (2014). Differing Pathways between Religiousness, Spirituality, and Health: A Self-Regulation Perspective. Psychology of Religion and Spirituality, 6, 9-21. https://doi.org/10.1037/a0034416

Al-Ibraheem, B., Kira, I., Aljakoub, J., \& Al-Ibraheem, A. (2017). The Health Effect of the Syrian Conflict on IDPs and Refugees. Peace and Conflict: Journal of Peace Psychology, 23, 140-152. https://doi.org/10.1037/a0034416

Bentler, P. M., \& Bonnet, D. C. (1980). Significance Tests and Goodness of Fit in the 
Analysis of Covariance Structures. Psychological Bulletin, 88, 588-606. https://doi.org/10.1037/0033-2909.88.3.588

Boals, A., \& Schuler, K. L. (2018). Reducing Reports of Illusory Posttraumatic Growth: A Revised Version of the Stress-Related Growth Scale (SRGS-R). Psychological Trauma: Theory, Research, Practice, and Policy, 10, 190-198. https://doi.org/10.1037/tra0000267

Braam, A. W. (2009). Religion/Spirituality and Mood Disorders. In P. Huguelet, \& H. Koenig (Authors), Religion and Spirituality in Psychiatry (pp. 97-113). Cambridge University Press. https://doi.org/10.1017/CBO9780511576843.008

Byrne, B. M., Shavelson, R. J., \& Muthén, B. (1989). Testing for the Equivalence of Factor Covariance and Mean Structures: The Issue of Partial Measurement Invariance. Psychological Bulletin, 105, 456-466. https://doi.org/10.1037/0033-2909.105.3.456

Caspi, A., Houts, R. M., Belsky, D. W., Goldman-Mellor, S. J., Harrington, H., Israel, S. et al. (2014). The P Factor: One General Psychopathology Factor in the Structure of Psychiatric Disorders? Clinical Psychological Science, 2, 119-137. https://doi.org/10.1177/2167702613497473

Chen, F. F. (2007). Sensitivity of Goodness of Fit Indexes to Lack of Measurement Invariance. Structural Equation Modeling, 14, 464-504. https://doi.org/10.1080/10705510701301834

Cohen, J. (1992). Statistical Power Analysis. Current Directions in Psychological Science, 1, 98-101. https://doi.org/10.1111/1467-8721.ep10768783

Danhauer, S. C., Case, L. D., Tedeschi, R., Russell, G., Vishnevsky, T., Triplett, K. et al. (2013). Predictors of Posttraumatic Growth in Women with Breast Cancer. Psycho-Oncology, 22, 2676-2683. https://doi.org/10.1002/pon.3298

Dennis, M. L., Chan, Y. F., \& Funk, R. R. (2006). Development and Validation of the GAIN Short Screener (GSS) for Internalizing, Externalizing and Substance Use Disorders and Crime/Violence Problems among Adolescents and Adults. American Journal on Addictions, 15, 80-91. https://doi.org/10.1080/10550490601006055

Gross, J. J., \& John, O. P. (2003). Individual Differences in Two Emotion Regulation Processes: Implications for Affect, Relationships, and Well-Being. Journal of Personality and Social Psychology, 85, 348-362. https://doi.org/10.1037/0022-3514.85.2.348

Hill, P. C., Pargament, K. I., Hood, R. W., McCullough, J. M. E., Swyers, J. P., Larson, D. B., \& Zinnbauer, B. J. (2000). Conceptualizing Religion and Spirituality: Points of Commonality, Points of Departure. Journal for the Theory of Social Behaviour, 30, 51-77. https://doi.org/10.1111/1468-5914.00119

Holmes, C., \& Kim-Spoon, J. (2016). Why Are Religiousness and Spirituality Associated with Externalizing Psychopathology? A Literature Review. Clinical Child and Family Psychology Review, 19, 1-20. https://doi.org/10.1007/s10567-015-0199-1

Hooper, D., Coughlan, J., \& Mullen, M. (2008). Structural Equation Modelling: Guidelines for Determining Model Fit. Electronic Journal of Business Research Methods, 6, 53-60.

John, O. P., \& Gross, J. J. (2004). Healthy and Unhealthy Emotion Regulation: Personality Processes, Individual Differences, and Life Span Development. Journal of Personality, 72, 1301-1334. https://doi.org/10.1111/j.1467-6494.2004.00298.x

Juang, L., \& Syed, M. (2008). Ethnic Identity and Spirituality. In R. M. Lerner, R. W. Roeser, \& E. Phelps (Eds.), Positive Youth Development and Spirituality: From Theory to Research (pp. 262-284). Templeton Foundation Press.

Kiesling, C., Sorell, G. T., Montgomery, M. J., \& Colwell, R. K. (2008). Identity and Spirituality: A Psychosocial Exploration of the Sense of Spiritual Self. Psychology of Reli- 
gion and Spirituality, $S$, 50-62. https://doi.org/10.1037/1941-1022.S.1.50

Kira, I. (2001). Taxonomy of Trauma and Trauma Assessment. Traumatology, 7, 73-86. https://doi.org/10.4236/psych.2019.104027

Kira, I. (2019). Toward an Integrative Theory of Self-Identity and Identity Stressors and Traumas and Its Mental Health Dynamic. Psychology, 10, 385-410. https://doi.org/10.4236/psych.2019.104027

Kira, I. (2021a). Taxonomy of Stressors and Traumas: An Update of The Development-Based Trauma Framework (DBTF): A Life-Course Perspective on Stress and Trauma. Traumatology. Advance Online Publication. https://doi.org/10.1037/trm0000305

Kira, I. (2021b). The Development-Based Taxonomy of Stressors and Traumas: An Initial Empirical Validation. Psychology, 12, 1575-1614. https://doi.org/10.4236/psych.2021.1210099

Kira, I., Abou-Mediene, S., Ashby, J., Lewandowski, L., Mohanesh, J., \& Odenat, L. (2012a). Post-traumatic Growth Inventory: Psychometric Properties of the Arabic Version in Palestinian Adults. The International Journal of Educational and Psychological Assessment, 11, 120-137.

Kira, I., Templin, T., Lewandowski, L., Ramaswamy, V., Bulent, O., Mohanesh, J., \& Abdulkhaleq, H. (2012b). Collective and Personal Annihilation Anxiety: Measuring Annihilation Anxiety AA. Psychology, 3, 90-99. https://doi.org/10.4236/psych.2012.31015

Kira, I., Templin, T., Lewandowski, L., Ashby, J. S., Oladele, A., \& Odenat, L. (2012c). Cumulative Trauma Disorder Scale: Two Studies. Psychology, 3, 643-656.

https://doi.org/10.4236/psych.2012.39099

Kira, I., Abou-Mediene, S., Ashby, J., Odenat, L., Mohanesh, J., \& Alamia, H. (2013). The Dynamics of Post-Traumatic Growth across Different Trauma Types in a Palestinian Sample. Journal of Loss and Trauma: International Perspectives on Stress \& Coping, 18, 120-139. https://doi.org/10.1080/15325024.2012.679129

Kira, I., Alawneh, A. N., Aboumediane, S., Mohanesh, J., Ozkan, B., \& Alamia, H. (2011). Identity Salience and Its Dynamics in Palestinians Adolescents. Psychology, 2, 781-791. https://doi.org/10.4236/psych.2011.28120

Kira, I., Ayna, Y. E., Shuwiekh, H. A. \& Ashby, J. S. (2021a). The Association of WTELS as a Master Motivator with Higher Executive Functioning and Better Mental Health. Current Psychology. https://doi.org/10.1007/s12144-021-02078-8

Kira, I., Özcan, N., Shuwiekh, H., Kucharska, J., Al-Huwailah, A., \& Bujold-Bugeaud, M. (2021b). Mental Health Dynamics of Interfaith Spirituality in Believers and Non-Believers: The Two Circuit Pathways Model of Coping with Adversities: Interfaith Spirituality and Will-to Exist, Live and Survive. Psychology, 12, 992-1024. https://doi.org/10.4236/psych.2021.126060

Kira, I., Shuwiekh, H., Al-Huwailah, A. H., Zidan, T., \& Bujold-Bugeaud, M. (2021c). Measuring Interfaith Spirituality: Initial Validation and Psychometrics. Psychology of Religion and Spirituality, 13, 324-339. https://doi.org/10.1037/rel0000242

Kira, I., Shuwiekh, H., Rice, K., Ashby, J. S., Alhuwailah, A., Sous, M., Baali, S., Azdaou, C., Oliemat, E., \& Jamil, H. (2021d). Coping with COVID-19 Continuous Complex Stressors: The "Will-to-Exist-Live, and Survive" and Perfectionistic Striving. Traumatology: An International Journal. Advance Online Publication. https://doi.org/10.1037/trm0000352

Kira, I., Clifford, D., Wiencek, P., \& Al-Haidar, A. (2001). Iraqi Refugees in Southeast Michigan: First Report. ACCESS Community Health and Research Center. 
Kira, I., Lewandowski, L., Templin, T., Ramaswamy, V., Ozkan, B., \& Mohanesh, J. (2008). Measuring Cumulative Trauma Dose, Types, and Profiles Using a Development-Based Taxonomy of Traumas. Traumatology, 14, 62-87. https://doi.org/10.1177/1534765608319324

Kira, I., Özcan, N. A., Shuwiekh, H., Kucharska, J., Al-Huwailah, A., \& Kanaan, A. (2020a) The Compelling Dynamics of "Will to Exist, Live and Survive" on Effecting PTG upon Exposure to Adversities: Is It Mediated, in Part, by Emotional Regulation, Resilience, and Spirituality. Traumatology: An International Journal, 26, 405-419. https://doi.org/10.1037/trm0000263

Kira, I., Shuwiekh, H., Kucharska, J., Al-Huwailah, A. H., \& Moustafa, A. (2020b). “Will to Exist, Live and Survive" (WTELS): Measuring Its Role as Master/Metamotivator and in Resisting Oppression and Related Adversities. Peace and Conflict: Journal of Peace Psychology, 26, 47-61. https://doi.org/10.1037/pac0000411

Kira, I., Shuwiekh, H., \& Kucharska, J. (2017a). Screening for Psychopathology Using the Three Factors Model of the Structure of Psychopathology: A Modified Form of GAIN Short Screener. Psychology, 8, 2410-2427. https://doi.org/10.4236/psych.2017.814152

Kira, I., Shuwiekh, H., Rice, K., Al Ibraheem, B., \& Aljakoub, J. (2017b). A Threatened Identity: The Mental Health Status of Syrian Refugees in Egypt and Its Etiology. Identity: An International Journal of Theory and Research, 17, 176-190. https://doi.org/10.1080/15283488.2017.1340163

Kira, I., Shuwiekh, H., Al Ibraheem, B., \& Aljakoub, J. (2019a) Appraisals and Emotion Regulation Mediate the Effects of Identity Salience and Cumulative Stressors and Traumas, on PTG and Mental Health: The Case of Syrian's IDPs and Refugees'. Self and Identity: The Journal of the International Society for Self and Identity, 18, 284-305. https://doi.org/10.1080/15298868.2018.1451361

Kira, I., Shuwiekh, H., Kucharska, J., \& Al-Huwailah, A. (2019b). The Integrated Structural and Measurement Models of Existential Annihilation Anxieties (EAA) and Their Potential Contribution to Clinical Science: Two Studies. Psychology, 10, 449-480.

https://doi.org/10.4236/psych.2019.104031

Kira, I., Shuwiekh, H., Alhuwailah, A., \& Balaghi, D. (In Press). Does COVID-19 Type III Continuous Existential Trauma Deplete the Traditional Coping, Diminish Health and Mental Health, and Kindle Spirituality? An Exploratory Study on Arab Countries. Journal of Loss and Trauma: International Perspectives on Stress \& Coping.

Kira, I., Templin, T., Lewandowski, L., \& Shuwiekh, H. (2018). A Conceptual Model and Measurement of Identity-Based, Existential Annihilation Anxieties (EAA). Psychology, 9, 1306-1328. https://doi.org/10.4236/psych.2018.96080

Kira, I., Templin, T., Lewandowski, L., Clifford, D., Wiencek, E., Hammad, A., Al-Haidar, A., \& Mohanesh, J. (2006). The Effects of Torture: Two Community Studies. Peace and Conflict: Journal of Peace Psychology, 12, 205-228. https://doi.org/10.1207/s15327949pac1203 1

Kira, I., Templin, T., Lewandowski, L., Ramaswamy, V., Bulent, O., Abu-Mediene, S., Mohanesh, J., \& Alamia, H. (2011). Cumulative Tertiary Appraisal of Traumatic Events across Cultures: Two Studies. Journal of Loss and Trauma: International Perspectives on Stress \& Coping, 16, 43-66. https://doi.org/10.1080/15325024.2010.519288

Koenig, H. G. (2009). Research on Religion, Spirituality, and Mental Health: A Review. The Canadian Journal of Psychiatry, 54, 283-291. https://doi.org/10.1177/070674370905400502

Laceulle, O. M., Vollebergh, W. A., \& Ormel, J. (2015). The Structure of Psychopathology 
in Adolescence: Replication of a General Psychopathology Factor in the TRAILS Study. Clinical Psychological Science, 3, 850-860. https://doi.org/10.1177/2167702614560750

Li, S., \& Berman, S. L. (2019). Spirituality and Adjustment: The Role of Identity. Journal of Spirituality in Mental Health, 22, 285-301. https://doi.org/10.1080/19349637.2019.1593068

Maercker, A., \& Zoellner, T. (2004). The Janus Face of Self-Perceived Growth: Toward a Two-Component Model of Posttraumatic Growth. Psychological Inquiry, 15, 41-48.

Mattis, J. S., \& Mattis, J. H. (2011). Religiosity and Spirituality in the Lives of African American Children. In N. E. Hill, T. L. Mann, \& H. E. Fitzgerald (Eds.), Child Psychology and Mental Health. African American Children and Mental Health, Vols. 1 and 2: Development and Context, Prevention and Social Policy (pp. 125-149). Praeger/ABC-CLIO.

Meredith, W. (1993). Measurement Invariance, Factor Analysis, and Factorial Invariance. Psychometrika, 58, 525-543. https://doi.org/10.1007/BF02294825

Meredith, W., \& Teresi, J. A. (2006). An Essay on Measurement and Factorial Invariance. Medical Care, 44, S69-S77. https://doi.org/10.1097/01.mlr.0000245438.73837.89

Monod, S., Brennan, M., Rochat, E., Martin, E., Rochat, S., \& Büla, C. J. (2011). Instruments Measuring Spirituality in Clinical Research: A Systematic Review. Journal of General Internal Medicine, 26, Article No. 1345. https://doi.org/10.1007/s11606-011-1769-7

Pargament, K. I., Desai, K. M., McConnell, K. M., Calhoun, L. G., \& Tedeschi, R. G. (2006). Spirituality: A Pathway to Posttraumatic Growth or Decline? In L. G. Calhoun, \& R. G. Tedeschi (Eds.), Handbook of Posttraumatic Growth: Research and Practice (pp. 121-137). Routledge.

Schnitker, S. A., Houltberg, B., Dyrness, W., \& Redmond, N. (2017). The Virtue of Patience, Spirituality, and Suffering: Integrating Lessons from Positive Psychology, Psychology of Religion, and Christian Theology. Psychology of Religion and Spirituality, 9, 264-275. https://doi.org/10.1037/rel0000099

Shaw, A., Joseph, S., \& Linley, P. A. (2005). Religion, Spirituality, and Posttraumatic Growth: A Systematic Review. Mental Health, Religion \& Culture, 8, 1-11. https://doi.org/10.1080/1367467032000157981

Tedeschi, R. G., \& Calhoun, L. G. (1996). The Posttraumatic Growth Inventory: Measuring the Positive Legacy of Trauma. Journal of Traumatic Stress, 9, 455-471. https://doi.org/10.1002/jts.2490090305

Templeton, J. L., \& Eccles, J. S. (2006). The Relation between Spiritual Development and Identity Processes. In E. C. Roehlkepartain, P. E. King, L. Wagener, \& P. L. Benson (Eds.), The Handbook of Spiritual Development in Childhood and Adolescence (pp. 252-265). SAGE Publications, Inc. https://doi.org/10.4135/9781412976657.n18

Van de Schoot, R., Lugtig, P., \& Hox, J. (2012). A Checklist for Testing Measurement Invariance. European Journal of Developmental Psychology, 9, 486-492.

https://doi.org/10.1080/17405629.2012.686740 


\section{Appendix. Interfaith Spirituality Scale and Its Short Form}

By Spirituality, we mean the feeling of a direct relationship with your creator, and your ability to transcend yourself. Also, (Creator means the power that put everything into existence, as you perceive/it). Please indicate how much the following statements apply to you according to the following scale.

(4) Mostly true about me (3) somewhat true about me (2). A little truth about me (1) Not True about me

1. I felt close to the creator (or to a Supreme being/power).

2. I directly sensed God's (or the Supreme being/power) presence. $\quad \begin{array}{lllll}1 & 2 & 3 & 4\end{array}$

3. I felt a bond with my creator (or the all-powerful force of being) $\quad \begin{array}{llll}1 & 2 & 3 & 4\end{array}$

4. My growing spiritual orientation (My direct relationship with the creator or the Supreme Being/ power as I feel or see it and my ability to transcend myself) is a deep motive for me. $\begin{array}{lllll}1 & 2 & 3 & 4\end{array}$

5. I feel a sense of well-being from my direct personal relationship with the creator (or to a Supreme being/power). $\begin{array}{llll}1 & 2 & 3 & 4\end{array}$

6. My feeling of direct connection with my creator gives me a sense of inner peace $\quad \begin{array}{lllllll}0 & 0 & 1 & 2 & 3 & 4\end{array}$ 7. I need to spend periods of time in private thought and reflection about life and existence. $\quad \begin{array}{lllll}1 & 2 & 3 & 4\end{array}$

8. I feel deep internal peace being so close to my creator. $\quad \begin{array}{lllll}1 & 2 & 3 & 4\end{array}$

9. I seek to get closer to my creator. $\quad \begin{array}{lllll}1 & 2 & 3 & 4\end{array}$

10. I feel that my creator is closer to me than my heart (My aorta). $\quad \begin{array}{lllll}1 & 2 & 3 & 4\end{array}$

11. I sense my creator's love directly and through others. $\quad \begin{array}{lllll}1 & 2 & 3 & 4\end{array}$

12. I got enriched spiritually from observing cosmic and natural beauty. $\begin{array}{lllll}1 & 2 & 3 & 4\end{array}$

13. I meditate about the miracle of creation and the meaning of existence. $\begin{array}{llllll}1 & 2 & 3 & 4\end{array}$

$\begin{array}{lllll}\text { 14. I have undescribed love to my creator. } & 1 & 2 & 3 & 4\end{array}$

15. I meditate about the creator's work in myself. $\quad \begin{array}{lllll}1 & 2 & 3 & 4\end{array}$

16. The substance of my spirituality is divine love. $\quad \begin{array}{lllll}1 & 2 & 3 & 4\end{array}$

17. To know about the creation and my being is one of my goals of existence. $\begin{array}{lllll}1 & 2 & 3 & 4\end{array}$

18. Controlling my extreme passion for material things promote my spirituality. $\begin{array}{llllll}1 & 2 & 3 & 4\end{array}$

19. Not wasting, and being satisfied with the little thing I may have, promote my spiritual feeling. $\quad \begin{array}{lllll}1 & 2 & 3 & 4\end{array}$

20. Modesty, being realistic and knowing the real value and limits of me promote my spiritual self. $\quad \begin{array}{lllll}1 & 2 & 3 & 4\end{array}$

21. The ability to control my wild desires and craves promotes my spiritual self. $\quad 1 \quad 2 \quad 3 \quad 4$

22. Being self-satisfied, grateful, and virtuous (e.g., being kind, fair, open-minded, having integrity, wisdom, and honesty) is part of my spiritual self.

$\begin{array}{llll}1 & 2 & 3 & 4\end{array}$

\section{Subscales and IFS-S-4 (short form) Keys}

1. Direct connection with the creator: $1,2,3,4.5 .6,8,9$

2. Asceticism, Self-discipline, and virtues: 18,19, 20, 21, 223

3. Meditation and Spiritual Knowledge: 7,10, 12, 13,15,17

4. Divine Love: $11,14,16$

Short Form Spirituality-S-4 (IFS-S-5): Items: 6, 13, 14, 20 